\title{
Gene Banking for Fish Germplasm Conservation
}

\section{SK Raghuvanshi* and S Kumar}

Limnology and Aquatic Biotechnology Lab, PG Department of Zoology, Bareilly

College, Bareilly-243005 UP, India.

*Corresponding Author: SK Raghuvanshi, Limnology and Aquatic Biotechnology

Lab, PG Department of Zoology, Bareilly College, Bareilly-243005 UP, India.
Received: September 01, 2021

Published: September 20, 2021

(C) All rights are reserved by SK Raghuvanshi and S Kumar.

\section{Abstract}

During recent years, the importance and need of fish biodiversity conservation has raised widespread concerns at global-level. This is because biodiversity is directly related to improvement of ecological productivity. The population of fishes is decreasing dayby-day due to changing climatic conditions as well as anthropogenic factors like, over-exploitation, habitat destruction, invasion of exotic species as well as urbanization and modernization. As a result, species extinction rate is thousand-times more as compared to the background rate. This emphasizes the need of developing and modernizing the fish seed production technology in eco-regime for stocking the water bodies and developing culture practices for long-term benefits of the inhabitants. In the present situation, where fish stocks are declining at alarming rate, conservation of fish germplasm resources can be considered as a promising and effective measure to counter the depletion rate in the future. Cryopreservation of gametes is basically a technique for storage of sperm/ova at very low temperature $\left(-196^{\circ} \mathrm{C}\right)$ for long period of time in viable and fertilizable sate. This paper emphasizes the importance of ex-situ conservation of fish germplasm through gene banking.

Keywords: Gene Banking; Germplasm; Fish Biodiversity; Ex-situ Conservation; Cryopreservation

\section{Introduction}

India is the second largest fish producing country in the world accounting for $6.56 \%$ of global production and contributing about $1 \%$ to the country's gross value added (GVA) and over $5.37 \%$ to the agricultural GVA. Fisheries and aquaculture continue to be an important source of food, nutrition, income and livelihood to millions of people. During 2017-18, export earnings from the fisheries sector has been Rs. 45106.89 crores which has registered an impressive average annual growth rate of about $19.11 \%$. the sector provides livelihood support to about 160 lakh people at the primary level and almost twice the number along the value chain and the annual average growth rate in the fisheries sector has been over $7 \%$ over the last few years [1].
Due to changing climatic conditions as well as anthropogenic interventions, the population of fishes is decreasing drastically. As a result, species extinction rate is thousand-times more as compared to the earlier times. Keeping the declining trend of fisheries resources in mind, there is more emphasis on ex-situ conservation of fish germplasm through the development of cryopreservation technique for the gametes of different fish species globally [2-12].

Gene banking through cryopreservation of gametes has now emerged as a promising and a very useful technique to facilitate artificial breeding for quality seed production in hatcheries and development of desirable gene pools. Besides commercial importance of cryopreservation technique in fish seed production, its applica- 
tion in conservation of fish biodiversity by developing gene-bank of depleting fish species is well recognized. Development of cryopreservation technique for the semen of different fish species and its application is of national and regional importance to augment fish food production in India and to conserve pristine fish germplasm resources. As far as the semen cryopreservation of Indian fishes is concerned, the work on freshwater Indian teleosts is very meager and limited [13-19].

The technology of cryopreservation of fish semen is one of the recent and applied branches of fishery research. It overcomes the problem of males maturing before females; allows availability of cryopreserved semen for artificial breeding in hatcheries and would greatly reduce the cost of maintenance of brood stocks. The development of a suitable and perfect cryopreservation technique for fish semen certainly boosts up the availability of stocking material (fish seed). The development of cryopreservation technique has opened new avenue for ex-situ conservation of the species by developing sperm/gene bank [20].

Blaxter (1953) reported the first successful fertilization of a marine fish, Clupea herengus eggs with cryopreserved sperm [21]. Since then, cryopreservation methods have been developed for sperm of more than 200 fish species with external fertilization $[22,23]$.

\section{Materials and Methods}

The study was carried out to measures and summarize the importance of conservation of fish genetic resources. In this regard, review of literature, reference study, browsing the internet for relevant data and new information from online sources, were carried by following the methods described by Bhuyan and Kashyap [20].

\section{Results and Discussion}

Why Conservation of fish germplasm is necessary?

Now-a-days, the importance of biodiversity and its conservation is well known. Aquatic systems sustaining fisheries and aquaculture, have undergone significant drastic alteration as a result of climatic change and anthropogenic interventions. Currently, there are 455 critically endangered fish species including 87 fish species, that are tagged as possibly extinct. Moreover, $3 \%$ of all evaluated fish species are listed as critically endangered. Furthermore, 16,298 species are threatened worldwide, in which 1,275 are fishes [24].
In Asia, 16.3\% endemic species are under the status of vulnerable [25]. The declining trend of biologically sustainable levels of fish stocks may increase even more, if careful coordination is not achieved in maintaining the resources. Thus, a combination of sound research and intensive efforts has become necessary for conservation of fish genetic resources in the present scenario [26].

\section{Strategies for Fish germplasm conservation}

For the propagation of any species, hatcheries play an important role by providing seeds for stocking. However, readily availability of viable milt is an important factor for the fish seed production in the hatcheries as well as in nature. To raise and maintain the male brooders in hatchery for extracting semen for artificial fertilization is a tedious and costly affair. Moreover, asynchronization of gonadal maturation is one of the major constraints that impede breeding [27]. Under each circumstance, it will be most advantageous to have a suitable means of preserving the viable gametes for artificial fertilization when needed. The gamete preservation is also helpful in the initiation of genetic selection programs by providing easy access to a reserve of genetic material of known and desired qualities.

Conservation of fish germplasm involves ex-situ mode, which means efforts aiming at preservation outside their natural aquatic habitat. The ex-situ conservation method of fish biodiversity involves three main pillars, viz. live gene banks, gene banks with gametes and gene bank with DNA [28]. The genetic information represented by a species can be maintained by conserving fish in wet or live gene banks. However, such banks suffer from two major drawbacks. Firstly, they offer no long-term guarantee of the genetic stability of the population or species over time and therefore captive stocks can't be maintained in a pristine condition [29]. Secondly, given the high natural genetic variation, it will be prohibitively expensive to maintain the desired representative genetic information of a population or species in a live gene bank.

To overcome these shortfalls, the genetic material (gametes) can be preserved in two ways. One of these is short-term preservation in which the sperm is stored from a few hours to a few weeks in an unfrozen state at sub-zero temperature, and the second alternative is long-term cryopreservation i.e., preservation of gametes along with suitable extender medium and cryoprotectants for longer duration in a frozen state at very low temperature $\left(-196^{\circ} \mathrm{C}\right.$ $\left.\pm 1^{\circ} \mathrm{C}\right)$. It makes possible almost indefinite storage of the desirable 
gene pools. Such gene/sperm banks can play a crucial role in the genetic management and conservation of aquatic resources. These sperm banks may also have additional applications in aquaculture. Genes from valuable individuals or stocks, which have desirable characteristics, can be preserved for future use and development.

The national prime institutes of ICAR viz., NBFGR, CIFE, CIFA are actively working in this field. Protocols have been developed for sperm cryopreservation of Indian major carps more or less simultaneously at the National Bureau of Fish Genetic Resource (NBFGR) and at the Central Institute of Freshwater Aquaculture (CIFA) in 1988. The optimum requirements have been developed in respect to extender, activation media, dilution rate, activation period, sperm-egg ratio for different species. Stocks of Labeo rohita semen cryopreserved in 1988 are being maintained along with other species in a mini gene bank at NBFGR. Viable hatchlings have been produced from five-year-old rohu cryopreserved semen [30].

On the other hand, attempts of ova cryopreservation have not yet been as successful as sperm. [31] reported the first successful cryopreservation of unfertilized ova and zygotes of salmonid fish. Ova frozen in liquid nitrogen $\left(\mathrm{LN}_{2}\right)$ at $-20^{\circ} \mathrm{C}$ for 5 minutes proved to be fertile and zygotes frozen at $-50^{\circ} \mathrm{C}$ survived the exposure. All subsequent attempts have failed. While it is difficult to predict possible advances in cryopreservation of fish gametes, it appears that the results so far are very promising.

The use of high-quality gametes from captive fish brood-stock is of great value for ensuring the production of vital offspring for aquaculture [32]. In commercial hatcheries, milt is often inadequate both in terms of quantity and quality and does not always give successful fertilization in the artificial breeding procedures commonly used for aquaculture practices. Therefore, at several stages of the fish farming and hatchery activities, there is a need for a reliable measure of sperm quality. The chemical and physical examination of milt have been an aid to the evaluation of reproductive ability in fish [33]. Since studies describing semen characteristics have shown large individual variation in the different parameters investigated [34], this rendered difficult the use of a single sperm characteristic to define good sperm quality.

The availability of several closely related species as well as distinct strains of fishes, a growing awareness of the importance of cross-breeding, and the existence of desirable genetic characteris- tics in one or other strain gives strength to the concept that several new husbandry techniques will be required in the future. Among them, the cryogenic storage of semen will probably be the most important. Short-term storage can be achieved simply by holding sperm at temperatures at or just above $0^{\circ} \mathrm{C}$. Sperm from selected males can be kept indefinitely by means of cryopreservation and be made available when and where required.

Attention on diverse facets of aquaculture, viz. receiving more healthy eggs, obtaining a good fertilization percentage by artificial breeding, developing new hatchery systems for good hatching rates, genetic upgradation of the desired fish species etc. have initiated a new era in fisheries [35-37]. The outcomes of these scientific studies have initiated a blue revolution in the country in recent years and are providing a better source of animal protein for the mal-nutrient populations, and best opportunities of employment for the vast populations.

\section{Conclusion}

The knowledge of timing of spawning (breeding season) of commercially important fish species is quite essential for artificial breeding and cryopreservation of the gametes. This is also important for rational management and sustainable exploitation of fishery resources. The information regarding spawning season is important in collection of ripe gametes and planning of artificial breeding schedule. This helps in managing artificial breeding experiments in proper time so that good results can be obtained. The development of technique for fish gametes cryopreservation of gametes of different indigenous fishes will go a long way in support of sustainability in aquaculture. It will also contribute in national repository as ex-situ conservation of fish gene pool.

\section{Bibliography}

1. Department of Fisheries, GOI. Handbook on Fisheries Statistics 2018. Ministry of Fisheries, Animal Husbandry and Dairying, Govt. of India, New Delhi (2019): 1-190.

2. Buyukhatipglu S and Holtz W. "Preservation of trout sperm in liquid or frozen state". Aquaculture 14 (1978): 49-56.

3. Stoss J and Holtz W. "Cryopreservation of rainbow trout (Salmo gairdneri) sperm. I. Effect of thawing solution, sperm density and interval between thawing and insemination". Aquaculture 22 (1981): 97-104. 
4. Legendre M and Billard R. "Cryopreservation of rainbow trout sperm by deep freezing". Reproduction Nutrition Development 20 (1980): 1859-1868.

5. Durbin H., et al. "A note on the cryopreservation of grass carp milt". Fish Management 13 (1982): 115-117.

6. Erdahl AW., et al. "Some factors affecting the preservation of salmonid spermatozoa”. Aquaculture 43 (1984): 341-350.

7. Rana KJ and McAndrew BJ. "The viability of cryopreserved tilapia spermatozoa". Aquaculture 76 (1989): 335-345.

8. Cloud JG., et al. "Cryopreservation of sperm as a means to store salmonid germplasm and to transfer genes from wild fish to hatchery populations". Progressive Fish-Culturist 51 (1990): 51-53.

9. Conget P., et al. "Cryopreservation of rainbow trout (Oncorhynchus mykiss) spermatozoa using programmable freezing". Aquaculture 143 (1996): 319-329.

10. Aoki K., et al. "Cryopreservation of Medaka Spermatozoa”. Zoology Science 14.4 (1997): 641-644.

11. Glogowski J., et al. "Cryopreservation of Muskellunge and yellow Perch semen". North American Journal of Aquaculture 61 (1999): 258-262.

12. Cabrita E., et al. "Cryopreservation of rainbow trout sperm in large volume straws: application to large-scale fertilization". Aquaculture 201 (2001): 301-314.

13. Kumar Kuldip. "Studies on cryogenic preservation of carp spermatozoa". In: Fish Genetics in India (Eds., P. Das and A.G. Jhingran) Today and Tomorrow's Printers and Publishers, New Delhi (India) (1989): 199-206.

14. Singh LB., et al. "Cryopreservation of fish spermatozoa". Nat. Bureau Fish Genet. Resources, Annual Report 1990-91 (1991): 46.

15. Lakra WS. "Cryogenic preservation of fish spermatozoa and its application to aquaculture". Indian Journal of Cryogenics 18.14 (1993): 171-176.
16. Basavaraja N., et al. "Short-term and long-term preservation of fish gametes with special reference to mahseer (Tor khudree) spermatozoa". Fishing Chimes 18.6 (1998): 17-19.

17. Gupta SD. "Preservation of carp milt". In: Training manual on breeding and hatchery management of carps for progressive Fish culture, CIFA, Bhubaneshwar (1999): 56-59.

18. Basheer VS., et al. "Milt cryopreservation of butter catfish, Ompok malabaricus (Val.)". Nat. Symp. Genetics and Gene Banking of Fish and Shellfish (29-30 March) (2003): 62.

19. Raghuvanshi SK. "Studies on the biology and cryogenic preservation of snowtrout (Schizothorax richardsonii) semen". D.Phil. Thesis submitted to HNB Garhwal University, Srinagar Garhwal (2008).

20. Bhuyan PC and Kashyap A. "An overview of fish germplasm conservation with special reference to mass awareness for ex-situ conservation". In: Conservation of Aquatic biodiversity (Eds. Bipul Phukan, Sangipran Baishya PC., et al. College of Fisheries, Assam Agricultural University (2020).

21. Blaxter JHS. "Sperm storage and cross-fertilization of spring and autumn spawning herring". Nature 172 (1953): 11891190.

22. Blesbois $\mathrm{E}$ and Labbe C. "Main improvements in semen and embryo cryopreservation for fish and fowl". In: Workshop of Cryopreservation of Animal Genetic Resources in Europe (Ed., D. Planchenault), Paris. (2003): 55-65.

23. Hiemstra SJ., et al. "The potential of cryopreservation and reproductive technologies for animal genetic resources conservation strategies". Proceeding of the Symposium on the Role of Biotechnology (5-7 March), Villa Gualino, Turin, Italy (2005): 25-35.

24. IUCN. "The IUCN Red list of threatened species". Version 20171 (2017).

25. NBFGR. "List of threatened freshwater fishes of India". National Bureau of Fish Genetic Resources, Lucknow (2010).

26. Goswami M., et al. "Bio-banking: An emerging approach for conservation of fish germplasm". Poultry, Fisheries and Wildlife Sciences 4 (2016): 143. 
27. Rawat US. "Reproductive strategies of a snowtrout Schizothorax richardsonii (Gray) in two riverine environments". D.Phil. thesis submitted to HNB Garhwal University, Srinagar Garhwal (2002).

28. Dar SA., et al. Conservation strategies for fish biodiversity (2019).

29. McAndrew BJ., et al. "Conservation and preservation of genetic variation in aquatic organisms". In: Recent Advances in Aquaculture IV (Eds., J.F. Muir and R.J. Roberts). Blackwell Scientific Publications, Oxford (1993): 295-336.

30. Ponniah AG. "Conservation of carp genetic resources of India. Proc. Collaborative research and training on genetic improvement of carp species in Asia”. CIFA, Bhubaneshwar (26-29 July) (1997).

31. Zell SR. "Cryopreservation of gametes and embryos of salmonid fishes". Annales de Biologie Animale, Biochimie, Biophysique 18 (1978): 1089-1099.

32. Bromage NR and Roberts RJ. "Preservation of gametes". In: Broodstock Management and egg and larval quality (Eds., N.R. Bromage and R.J. Roberts). Blackwell Science, Oxford (1995): 53-75.

33. Cruea DD. "Some chemical and physical characteristics of fish sperm". Transactions of the American Fisheries Society 98 (1969): 785-788.

34. Dreanno C., et al. "Effect of urine on semen quality in turbot (Psetta maxima)". Aquaculture 169 (1998): 247-262.

35. Jhingran VG and Pullin RSV. "A hatchery manual for the common, Chinese and Indian Major Carps". Asian Development Bank and International Centre for Living Aquatic Resources Management, Manila, Philippines (1985): 191.

36. Dehadrai PV. "Carps seed production in India”. In: Summary report of the Asian Regional Workshop on carp hatchery and nursery technology (Eds., R.C. May, R.S.V. Pullin and V.G. Jhingran), Manila, Philippines (1-3 February). Asian Development Bank and I.C.L.A.R.M., Manila, Philippine (1986).
37. Shrestha, TK. "Artificial Himalayan mahseer spawning: A monograph". Tribhuan University, Kathmandu, Nepal (1986).

Volume 3 Issue 10 October 2021 (C) All rights are reserved by SK Raghuvanshi and S Kumar. 